\title{
高シリカ $\mathrm{Y}$ 型ゼオライトの合成
}

(1990 年 7 月 25 日受理)

吉田章

$\mathrm{SiO}_{2} / \mathrm{Al}_{2} \mathrm{O}_{3}$ モル比が 5.5 6.0 のY型ゼオライトを合成し， $\mathrm{Y}$ 型ゼオライトの生成過程に叔ける固 相および夜相の変化を粉末 X線回折分析, 魔法角 NMR, 二次電子像観察, および組成の化学分析によ

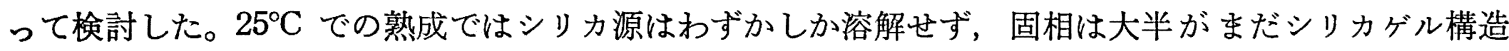
をとるが，液相組成はアルミナに富む組成で多数の核の生成が行われる。100 $\mathrm{C}$ での結晶化では固相は 速やかに前駆的固相に変化し， ${ }^{29} \mathrm{Si}-\mathrm{NMR}$ のシグナルは高磁場側から低磁場側ヘシフトする。バッチ組 成の $\mathrm{Na}_{2} \mathrm{O} / \mathrm{SiO}_{2}$ モル比が低くなると自触的核生成が抑制され，還元結晶化時間を用いる生成率曲線は $\mathrm{S}$ 字型から直線に近い形となる。液相組成は $\mathrm{Na}^{+} / \mathrm{SiO}_{2}$ モル比が減少し, 結晶化過程で $\mathrm{Na}^{+} / \mathrm{SiO}_{2}$ モ ル比が 0.84 以下になる系ではホージャサイト型ゼオライトのほかにリョウフッ石とグメリナイトが生 成した。ゼオライトの生成過程は液相一固相説で説明できた。

\section{1 緒言}

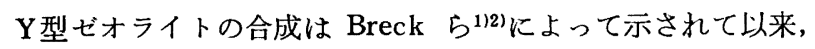
多くの研究者によって改良され，確立されている( ${ }^{3) 199}$ 。高シリカ Y 型ゼオライトを合成する方法としては，活性なケイ酸ナトリウ ムを使用する方法4), 合成用組成物に核発生中心となるゲル5)，お

九州工業技術試騟所資源開発部資源化学課, 841 鳥栖市 宿町

1) D.W. Breck, U.S.P., 3, 130, 007(1964).

2) D. W. Breck, E. M. Franigen, "Molecular Sieves", Soc. Chem. Ind., London, (1964) p. 47.

3) H. E. Robson, U.S. P., 1, 041, 453(1964).

4) T. V. Whittam, U. K. P., 1, 145,995(1969), U.S.P., 4, 016, 246(1977).

5) C. V. McDaniel, P. K. Maher, J. M. Pilato, U.S.P., 4, 166, 099(1979).

6) H. Kacirek, H. Lechert, J. Phys. Chem., 79, 1589 (1975).

7) H. Kacirek, H. Lechert, ibid., 80, 1291(1976).

8) D. E. W. Vaughan, G.C. Edwards, M. G. Barrett, U. S. P., 4, 178, 352(1979).

9）ウイリアム・ブルース・ウイルソン，特開昭 49-61096 (1974).

10) デビッド・エバン・ウイリアム・ボーガン, マイィル・ジ ョーシ・バレット, 特開昭 57-77024(1982).

11) C. H. Elliot, Jr., U. S. P. 4, 164, 551(1979).

12) 結城 䇏, 特開昭 57-140314(1982).

13) 有家潤二, 相本道行, 宮崎 弘, 特開昭 59-64521 (1984).

14）クラント・キャンベル・エドワーズ，ロバート・リン・チ ヤン, 特開昭 59-121114 (1984).

15） ヘルトラン・ラトゥーレット，レシ・ボワソン，特開昭 59-207832(1984).

16) 有家潤二, 相本道行, 宮崎 弘, 特開昭 59-22715(1984).

17) 宮崎 弘, 有家潤二, 相本道行, 特開昭 61-21911(1986).

18）吉田 章, 井上耕三, 特開昭 61-91013(1986).

19) W. B. Wilson, Brit. Appl. 1,431,944(1976).
よびX型ゼオライトを涯加する方法677), 合成の途中でバッチ組成 の $\mathrm{SiO}_{2} / \mathrm{Al}_{2} \mathrm{O}_{3}$ モル比を 65〜135 に上げる方法"), ソーダライト ヶージの中に $\mathrm{Cs}^{+}$イオンを捕獲することを特徵とする方法 ${ }^{11}$, 原 料を粒状無定形アルミノケイ酸塩とした後結晶化させる方法 ${ }^{16)}$, および第四級アンモニウム塩を使用する方法 ${ }^{200}$ などが報告されて いる。生成するY型ゼオライトの $\mathrm{SiO}_{2} / \mathrm{Al}_{2} \mathrm{O}_{3}$ モル比は 6.0 を越 えると報告されているものもある416771911117119)が，第四級アンモ二 ウム塩を使用する例20)以外は, $\mathrm{SiO}_{2} / \mathrm{Al}_{2} \mathrm{O}_{3}$ モル比が 6 を越える $\mathrm{Y}$ 型ゼオライトの合成は可能であっても極めて難しい(21)22)のが現状 であろう。また，Kacirek らが報告しているよらに，Y型ぜオラ イトの線成長速度は $\mathrm{SiO}_{2} / \mathrm{Al}_{2} \mathrm{O}_{3}$ モル比が高くなるにつれていち じるしく遅くなる゙ために，再現性が悪い例も多い。

Y 型ゼオライトの合成法の改良が迅速合成法(6) や合成廃液の再 利用 ${ }^{11}$ にまでおよんでいるにもかかおらず，反応過程が完全に把 握されているわけではないので, 合成条件の微妙な变化に対し ては, 操作条件を设調整して新たに安定的に生成しらる条件を求 める必要がある。出発原料が異なる場合や，同じ原料でもその混 合条件や熟成条件が異なると, 目的とするゼオライトの生成率が 低下したり，他の安定相に属するゼオライトが生成するのはよく 知られた事実である ${ }^{23 \sim 341}$ 。また，ゼオライトの生成過程の完全な 把握が極めて困難なのは, Barrer ${ }^{35)}$, Sand ${ }^{36)}$ および Flanigen ${ }^{37)}$

20）デイヴイッド・エヴアン・ウイリアム・ボーン，カールゴ ットリープ・ストローマイヤー, 特開平 1-164719(1989).

21) C. Y. Li, L. V.C. Rees, Zeolites, 1986, 51.

22) H.Stach, U. Lohse, H. Thamm, W. Schirmer, ibid., 1986, 74 .

23) R. M. Barrer, "Hydrothermal Chemistry of Zeolites", Academic Press, (1982) p. 170, p. 216-246.

24) B. M. Lowe, N. A. MacGilps, T. V. Whittam, "Proceedings of the Fifth Conference on Zeolites", Ed. L. V. Rees, Heyden, London (1980) p. 85.

25) F. Polak, A.Cichocki, "Molecular Sieves", Amer. Chem. Soc., Washington (1973) p. 209. 
らが指摘したように，ほとんどの系で不安定な中間生成物（非晶 質固相）が生成与る上に, 複数のゼオライト種の同時進行的生成 が可能であることに因っている。

高シリカY型ゼオライト合成時に副生する主要な他のゼオライ ト種はリョウフッ石とグメリナイトである。Y型ゼオライトの標 準物として広く使用されている U.C.C. 社の LZ-Y 52 にも,グメ

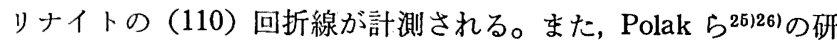
究でシリカゾルと水酸化ナトリウム溶液との接触時間を長くした 系でホージャサイト型ゼオライトの代わりに生成したのがグメリ ナイトであった。りョウフッ石はY型ゼオライトとほとんど同じ $\mathrm{SiO}_{2} / \mathrm{Al}_{2} \mathrm{O}_{3}$ モル比を有する $\left.{ }^{38}\right)$ が, 細孔構造が小さなグメリナイト はホージャサイト型ゼオライトより少し高い $\mathrm{SiO}_{2} / \mathrm{Al}_{2} \mathrm{O}_{3}$ モル比 を有寸る ${ }^{39 \%}$ 。これらのゼオライト種は既報40で報告したよらにそ の微細構造がホージャサイト型ゼオライトのそれと酷似してお り， 2 種類の結晶は均一な球状の結晶粒を形成している場合が多 (40141)。高シリカY型ゼオライトの生成を妨げるこの球状晶がど のよらな条件で生成するのか，逆に，ホージャサイト型ゼオライ 卜の生成に必要不可欠な非晶質固相括よびそれに含まれる液相の 条件は何であるのかはまだほとんど解明されていない。本研究で は高シリカY型ゼオライトとリョウフッ石, グメリナイト系球状 晶が生成する領域での液相, 抽よび固相の变化を観察し，Y型ゼ オライトの生成条件を険討したので報告する。

\section{2 実験}

\section{1 合成方法}

シリカ源は日本シリカ工業(株)の超微粒子ヶイ酸 (VN-3)，お

26) F. Polak, E.Stobiecka, Bull. Acad. Pol. Sci., Ser. Sci. Chim., 26, 899(1978).

27）白崎高保, 小林正弘, 岡崎 洪, 森川 清, 工化, 72, 1041(1969).

28）板橋慶治，笠原泉司，高石哲男，日化，1989，318.

29) S. Kasahara, K. Itabashi, K. Igawa, "New Developments in Zeolite Science and Technology", (Eds. Y. Murakami, A. Iijima, J. W. Ward), Kodansha (1986) p. 185.

30）桶野良治，土岐堅次，日化，1977，593.

31) R. Hino, R. Matuura, K. Toki, Bull. Chem. Soc. $J p n ., 56,1883(1983)$.

32) R. Hino, H. Aoi, K. Toki, Bull. Chem. Soc. Jpn., 57, 317(1984).

33) F. E. Schwochow, G. W. Heinze, "Moleular Sieves Zeolites-1", Amer. Chem. Soc., Washington (1971) p. 102.

34) A. Yoshida, K. Inoue, Zeolites, 1988, 94.

35) R. M. Barrer, "Hydrothermal Chemistry of Zeolites", Academic Press (1982) p. 134.

36) L. B. Sand, "Proceeding of the Fifth International Conference on Zeolites", (Ed. L.V. Rees), Heyden, London (1980) p. 1.

37) E. M. Flanigen, "Molecular Sieves", Amer. Chem. Soc., Washington (1973) p. 119.

38) S. P. Zhdanov, "Molecular Sieves", Soc. Chem. Ind., London, (1968) p. 70.

39) R. H. Daniels, G. T. Kerr, L.D. Rollmann, J. Am. Chem. Soc., 100, 3097(1978).

40）吉田 章, 井上耕三，川村圭一，日化，1985，14.

41）吉田 章, 井上耕三, 九州工業技術試験所報告, No. 44, 2783(1990).

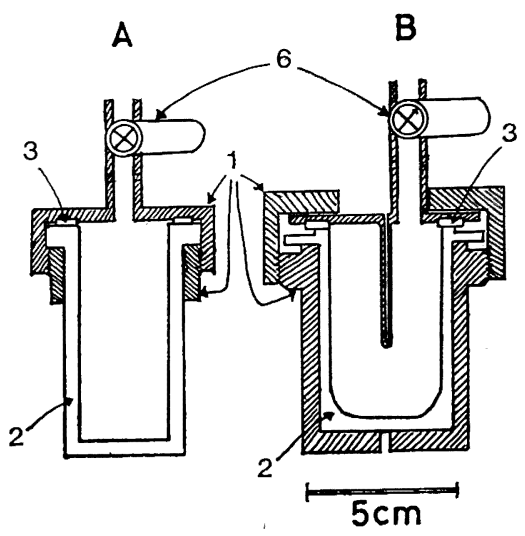

C

Fig. 1 Reaction vessel for zeolitization

1: Stainless steel, 2: Teflon, $3:$ Teflon packing, 4 :

Sintered-stainless steel filter, $5:$ Rubber packing, 6 : Cock

$A$ and $B$ are for long reaction time or under high pressure, $\mathrm{C}$ is for the centrifugal separation of liquid phase

よび触媒化成工業(株)のシリカゾル（S-30 H， SI 30 および SA) を使用した。アルミナ源は三井アルミナ製造(株)の水酸化アルミ ニウム $\left(\mathrm{Al}_{2} \mathrm{O}_{3}=63.4 \%\right)$ を高杉製薬(株)の水酸化ナトリウム溶 液（ $\mathrm{NaOH}=48 \%)$ 飞溶解したアルミン酸ナトリウム溶夜を使用 した。

反応容器は $100 \mathrm{~cm}^{3}$ のステンレス鋼製ビーカーおよび, 図 1 に 示した反応容器を使用した。ステンレス鋼製ビーカーの上部は二 方コックのついたゴム栓で封じた。長期間の加熱を要する場合や 加圧下での結晶化には反応容器 $\mathrm{A}$ および $\mathrm{B}$ を用いた。反応容器 $\mathrm{A}$ およびBの接液部はいずれもテフロン製で, 密閉用外鞘はステン レス鋼製である。所定の組成に調製したアルミン酸ナトリウム溶 液にシリカゾル $\left(25 \sim 300 \mathrm{~cm}^{3}\right)$ を加えてテフロン棒でかき混ぜ た後, ウルトラディスパーサー (ヤマト科学(株)) で 0 120 秒 間かき混ぜた。また，あらかじめ反応容器に超微粒子ヶイ酸を加 えて拈き，所定の組成に調製したアルミン酸ナトリウム溶液を加 えてミクロスパーテルでかき混ぜて糊状の均一な反応混合物とし た。東洋曹達工業(株)製合成ゼオライト F-9（粉末，200 メッシ ュ，Na-X型ゼオライト）をめのら製ボールミルで1時間湿式で 粉䂗したものを種晶とした。種晶スラリー $\left(0.1 \mathrm{~g} / \mathrm{cm}^{3}\right)$ はピペッ トで分取して生成物重量の大略 $1 \%$ を添加した。

反応混合物のバッチ組成は $\mathrm{Na}_{2} \mathrm{O} / \mathrm{SiO}_{2}$ モル比, $\mathrm{SiO}_{2} / \mathrm{Al}_{2} \mathrm{O}_{3}$ モ ル比拈よび $\mathrm{H}_{2} \mathrm{O} / \mathrm{Na}_{2} \mathrm{O}$ モル比で表される。便宜上, 本報告では バッチ組成を 0.3-10-40 のよらに書き, $\mathrm{Na}_{2} \mathrm{O} / \mathrm{SiO}_{2}$ モル比= 0.3, $\mathrm{SiO}_{2} / \mathrm{Al}_{2} \mathrm{O}_{3}$ モル比=10 および $\mathrm{H}_{2} \mathrm{O} / \mathrm{Na}_{2} \mathrm{O}$ モル比 $=40$ の 組成を示す。また，バッチ組成の $\mathrm{Na}_{2} \mathrm{O} / \mathrm{SiO}_{2}$ モル比は $\mathrm{N}, \mathrm{SiO}_{2} /$ $\mathrm{Al}_{2} \mathrm{O}_{3}$ モル比は $\mathrm{S}$ と略記する。

反応混合物は $25^{\circ} \mathrm{C}$ の恒温水槽に 40 分〜 24 時間ひたして, 熟 成した後, $90 \sim 99.5^{\circ} \mathrm{C}$ の恒温水槽, または $105.2^{\circ} \mathrm{C}$ の油浴に静

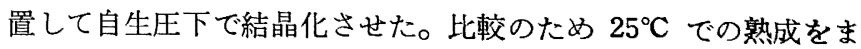
ったく行わない系についても結晶化を試みた。所定の時間後に容 器の内容物を取り出し, 液相は反応混合物を遠心分離した後, 先 端に脱脂綿を付けたタイゴン管を装着したピペットで分取した。 また，異なる遠心効果で $2 \sim 4$ 回に分けて液相を分取する場合に は，蒸発による水分量の变化を防ぐためにステンレス鋼製遠心管 
型反応容器 (図 $1 \mathrm{C}$ ) を用いた。焼結板で仕切った上部に反応混 合物を入れ, 蓋をした後, 反応容器を逆さまにして加熱した。反 応容器の底部は部分的に液相を遠心分離する度に, 新しいものと 取り替えた。固相は漏斗で吸引沪過し, $2 \mathrm{dm}^{3}$ の蒸留水で洗浄 し, $110^{\circ} \mathrm{C}$ で乾燥した後, デシヶーターに入れた $3 \mathrm{M}$ の $\mathrm{NaCl}$ 溶液上（相対湿度 75〜80\%）で一昼夜以上静置して吸湿させた。

\section{2 化学分析}

液相のシリカは $3.5 \mathrm{M}$ の水酸化ナトリウム溶液を加えて $99.5^{\circ} \mathrm{C}$ で加熱しケイ酸オリゴマー42)を分解した後，モリブデン 黄法で定量した。アルカリ量は $0.2 \mathrm{M}$ の塩酸で中和滴定法で求 め, さらに Zn-EDTA 逆滴定法によりアルミニウムを定量した。 固相はアルカリ溶融した後, シリカとアルミナを定量した。また, フッ化水素酸でシリカを除去した後, 原子吸光分光光度法でナト リウムを定量した。

\section{3 物 性 測 定}

既報の方法で粉末 $\mathrm{X}$ 線回折法により, 固相に含まれるゼオライ トの定量 ${ }^{40143)}$ と格子定数44) 測定を行った。LZ-Y 52 を結晶含有 率 $100 \%$ のY型ゼオライト ( Na 型) 標準物として使用した。 $\mathrm{Y}$ 型ゼオライトの定量は $2 \theta$ が 6 32 な回折線の高さの和を, 標準物の和で除した值を用いて行っ た ${ }^{43)}$ 。主要な回折線がリョウフッ石の幅の広い回折線と重なる場 合には，その影響を排除すべくベースラインを設定した。また， 既報 ${ }^{40)}$ で報告したように Y 型ゼオライトの (111) 回折線の面積 を標準物のそれで除した值を求めて, 回折線の高さの和から求め た值と比較した。また, 重複する回折線の分離は既報 ${ }^{40)}$ と同様に 行った。リョウフッ石とグメリナイトの量は両者の和で表し40), 今回の試料中でリョウフッ石とグメリナイトの主回折線の面積の 和が最大のものを標準試料とした。この試料は $7.1 \%$ の 型ゼオ ライトを含むので, $92.9 \%$ の結晶度とした。P型ゼオライトの定 量も既報 ${ }^{40)}$ と同様に行った。

二次電子像は卓上型走査電子顕微鏡（日立-明石社製, MSM-9 型）で観察した。

固相の ${ }^{29} \mathrm{Si}-\mathrm{MASNMR}$ の測定は既報 ${ }^{43)}$ と同様に行った。

\section{3 結果}

\section{$3.1 \mathrm{Y}$ 型ゼオライトの生成に影響を与える諸要因}

シリカゾルを用いる場合には, ウルトラディスパーサーによる かき混ぜ時間が $\mathrm{Y}$ 型ゼオライトの最大生成率に影響を与えた（図 2)。9 $90^{\circ} \mathrm{C}$ おび $99.5^{\circ} \mathrm{C}$ で結晶化した例では, いずれの場合も テフロン棒でかき混ぜただけのものより, ウルトラディスパーサ 一でさらに 10〜30 秒間かき混ぜた系の方が結晶化速度が速く, $99.5^{\circ} \mathrm{C}$ では最終的な結晶化度もよくなった。また, シリカゾルと アルミン酸ナトリウム溶液の混合の順序は, 生成率曲線にほとん

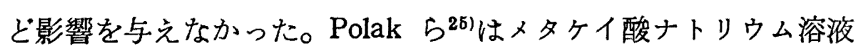
をシリカ源とする場合に混合の順序によって, 生成するゲル固相 とゲルに含まれる液相の組成に大きな差が認められたと報告して いる。また, Barrer ${ }^{23)}$ はX型ゼオライトの生成に扎いて，かき鼬

42) B. Fahlke, P. Stark, V. Seefeld, W. Wieker, K. P. Wendlandt, Zeolites, 1987, 209.

43) A. Yoshida, Y. Adachi, ibid., 1989, 111.

44) A. Yoshida, K. Inoue, Y. Adachi, The Reports of the Government Industrial Research Institute, Kyushu No.43, 2745(1989).

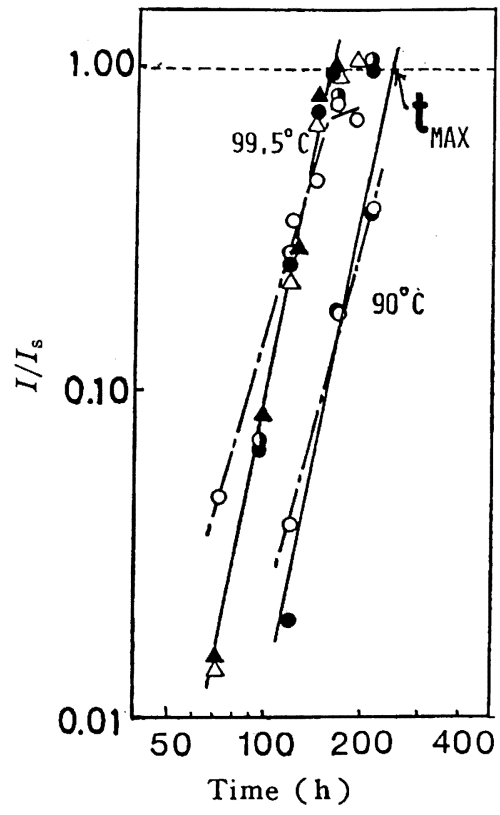

Fig. 2 Effect of premixing of reaction mixtures with ultra dispersor

Silica source $=40 \mathrm{~cm}^{3}$ of SI-30. N-S-H=0.29610. 9-40, Ageing; $25^{\circ} \mathrm{C}, 24 \mathrm{~h},(\mathrm{O})$ mixed by hand with Teflon rod, mixing time with dispersor;

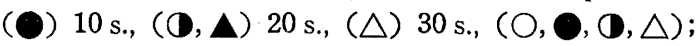
Sodium aluminate solution was added to sol, (A); sol was added to sodium aluminate soltion. $\mathrm{N}=\mathrm{Na}_{2} \mathrm{O} / \mathrm{SiO}_{2}, \mathrm{~S}=\mathrm{SiO}_{2} / \mathrm{Al}_{2} \mathrm{O}_{3}, \mathrm{H}=\mathrm{H}_{2} \mathrm{O} / \mathrm{Na}_{2} \mathrm{O}$. $I$ means the sum of peak heights of 10 lines in the range of $6-32^{\circ}, I_{\mathrm{s}}$ means that of LZ.-Y 52 .

ぜが衝突による $\mathrm{P}$ 型ゼオライトの核生成を有利にすると報告して いるが, シリカゾルを原料とする場合では, 短時間のアルミン酸 ナトリウム溶液との接触では溶解するシリカの量が少ない(12)251 26)30 32142145) ことから，かき混ぜはシリカゾルとアルミン酸ナトリ ウム溶液との混合以上の作用はしていないものと考えられる。

生成量と結晶化時間の両対数プロットの勾配はかき混ぜた系で 5.0〜5.1，かき混ぜなかった系で 3.6〜3.7 であった。Ciric ${ }^{46)}$ が

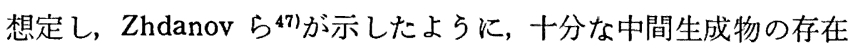
下で結晶化初期からかなり結晶化の進んだ時点までの結晶の線成 長速度が一定であるとすると, 結晶化過程で核が生成しない場合

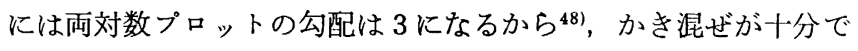
ない系でも, 結晶化過程でひき続き核生成が行われていることに なる。また，十分にかき混ぜた系では結晶化の初期に自触的核生 成 ${ }^{48)}$ が行われていることになる。

図 3 に異なるシリカ源を用い，バッチ組成が 0.286-10-42.0 から 0.297-9.71-40.7 の範囲で生成する $\mathrm{Y}$ 型ゼオライトの生

45) D. M. Ginter, C. J. Radke, A. T. Bell, "Zeolites : Facts, Figures, Future", (Eds. P. A. Jacob, R. A. van Santen), elsevier (1989) p. 161.

46) J. Ciric, J. Colloid. Interface Sci., 28(2), 315(1968).

47) S.P. Zhdanov, N. N. Samulevich, "Proceedings of the Fifth International Conference on Zeolites", (Ed. L. V. Rees), Heyden, London (1980) p. 75.

48) S.P.Zhdanov, "Molecular Sieves-I", Amer. Chem. Soc., Washington (1971) p. 20. 


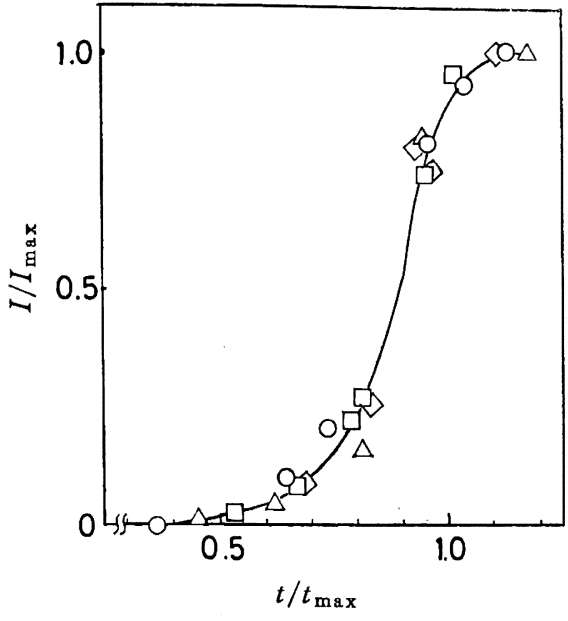

Fig. 3 Crystallization curves of zeolite Y from different silica sources

(O) VN-3, N-S-H=0.297-9.71-40.7, ( $\triangle$ ) S$30 \mathrm{H}, 0.292-9.81-41.9$, (口) SI-30, 0.292-1041. 1, ( $\diamond) \mathrm{SA}, 0.286-10-42,(\triangle, \square, \diamond)$; premixed with ultra dispersor for $30 \sim 35 \mathrm{~s}$.

(O) ; premixed with small spoon by hand, Age-

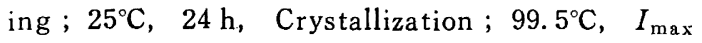
means the maximum yield of zeolite $\mathrm{Y}$. For identification of $t_{\max }$ and $\mathrm{N}, \mathrm{S}, \mathrm{H}$, see in Fig. 2 and Fig. 2 legend

成率と還元結晶化時間の関係を示した。生成率と結晶化時間の両。 対数プロットで得られる直線が生成率 $100 \%$ を切る時間（図 2 の $t_{\max }$ ）を結晶化完了時間とし, 結晶化時間を $t_{\max }$ で除した ものを還元結晶化時間とした。バッチ組成とシリカ源が異なるに もかかわらず還元結晶化時間で表した結晶化曲線がよく一致する ことから，今回使用したシリカ源ではその一次粒子径および凝集 状態の差はY型ゼオライトの生成（核の生成，成長および自触的 核生成）に顕著な影響を与えず，前述のバッチ組成の範囲で極め て安定的に生成するものと考えられる。

次に, 0.28-10.0-42.8のバッチ組成で, 初期ゲルの調製方法 がY型ゼオライトの生成に与える影響を検討した。室温で原料溶 液を混合し，ウルトラディスパーサーで 1 分間かき混ぜた後，た だちに昇温した場合と，24 時間 $25^{\circ} \mathrm{C}$ で熟成した後, 結晶化した 場合では，いずれもY型ゼオライトが生成した（図 4-1，-2）。か き混ぜ直後に昇温した系では, 反応混合物を反応容器に等分に分 取する作業などに大略 30 分間を要した。Breck ら ${ }^{1 / 2)}$ の報告に反 して，室温に特ける熟成が十分でなくても，結晶化が遅延するだ けでLZ-Y 52 と同等の生成率を示寸試料が得られた。また，生成 物量と絬晶化時間の両対数プロットの勾配は熟成した系で 6.9, 熟成しなかった系では 5.4 で，この結果は熟成しない場合にも結 晶化過程で自触的核生成が生じていることを示している。

初期ゲルの室温での熱履歴をこれ以上短縮するわけにはいかな いので，あらかじめ結晶化温度に加熱した原料溶液を混合して結 晶化したところ，生成率に若干のばらつきがみられたが，主とし て（リョウフッ石十グメリナイト）が生成し（図 4-3），10\%以 下の $\mathrm{P}$ 型ゼオライトと $4.3 \%$ 以下のY型ゼオライトが副生した。 この場合には, ウルトラディスパーサーによるかき混ぜ, 容器へ の分取と密閉は室温下で行ったので, 初期ゲルは室温近くまで泠

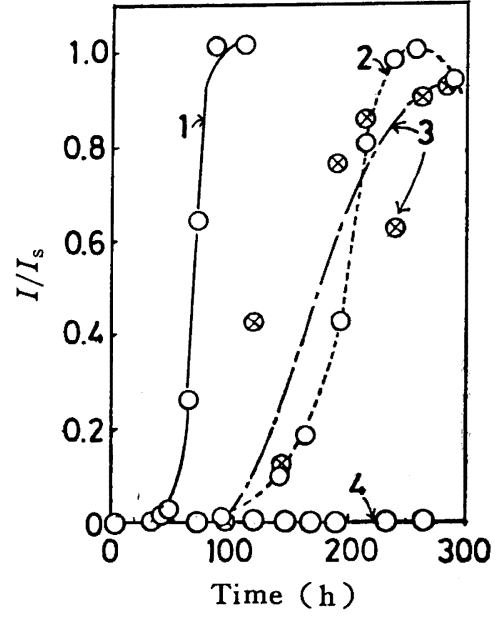

Fig. 4 Effects of the premixing conditions

1 : premixed at room temperature and aged at $25^{\circ} \mathrm{C}$ for $24 \mathrm{~h}, 2$ : premixed at room temperature, 3 : preheated sol and sodium aluminate solution at $99.5^{\circ} \mathrm{C}$ were premixed in air, $4:$ preheated sol and sodium aluminate soln. were premixed at $99.5^{\circ} \mathrm{C}$, Crystallization ; $99.5^{\circ} \mathrm{C}$, (O) zeolite $\mathrm{Y},(\otimes)$ chabazite + gmelinite, $\mathrm{N}-\mathrm{S}-\mathrm{H}=0.281-10-42.8$ for 1,2 , and 3 , and $0.286-10-41.6$ for 4 . Silica source is SA. For identifications of $I / I_{B}$, see Fig. 1 legend.

却していた。 $99.5^{\circ} \mathrm{C}$ に加熱した原料溶夜を混合すると瞬時に反 応して反応混合物は大きな硬い塊となる。この塊はテフロン棒お よびウルトラディスパーサーで解砕したが，室温で混合した系の ような糊状の均一な混合物とならず，砂状の塊を含んでいた。こ の不均一な混合状態が他の系では生成しなかった $\mathrm{P}$ 型ゼオライト の生成を可能にし，また，主生成物のリョウフッ石扣よびグメリ ナイトの生成率にばらつきを生じた原因であると考えられる。な お，（リョウフッ石十グメリナイト）のX線回折強度に占めるグ メリナイトの比率は 19〜28\% で，Y型ゼオライトに少量副生す る球晶状のもの（グメリナイトが 24〜35\%) にくらべて少し低か った。しかし、リョウフッ石の回折線は球晶状のものと同様に極 めて半值幅が広かった。

混合用容器を沸騰水にひたして，あらかじめ $99.5^{\circ} \mathrm{C}$ に加熱し た原料溶液を混合し，かき混ぜおよび容器への分取中も保温した 場合には 11 日間の結晶化時間でいずれのゼオライ゚ト種も生成し なかった（図 4-4）。生成物の二次電子像を図 5 に示した。

加熱した原料溶液を混合した場合に生成するリョウフッ石とグ メリナイトを図 5-1 に示した。この試料は今回(リョウフッ石十 グメリナイト）の標準試料に使用したもので, 直径 $15 \mu \mathrm{m}$ の粗粒 を含儿で㧍り，Y型でオライトの生成時に少量副生する球晶状の ものも散見されるが，晶癖面はそれほどはっきりしていない。高 温で混合するとY型ゼオライトの核生成が抑制されるのは, 板橋 $5^{281}$, Kasahara ら291の結果とよく一致している。また, シリカ原 料の凝集状態がY型ゼオライトの生成率に影響を与えていること は想像に難くない(1)が，室温で混合し熟成を行わなかった系で は, 生成したY型ゼオライトは熟成した系（図 5-2）にくらべて 粒径が大きく（図5-3）, 生成するY型ゼオライトのほとんどが粗

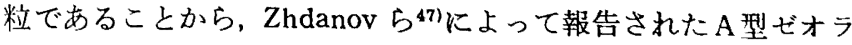
イトやX型ゼオライトの例と同様に, 室温での熟成時間が短いも 


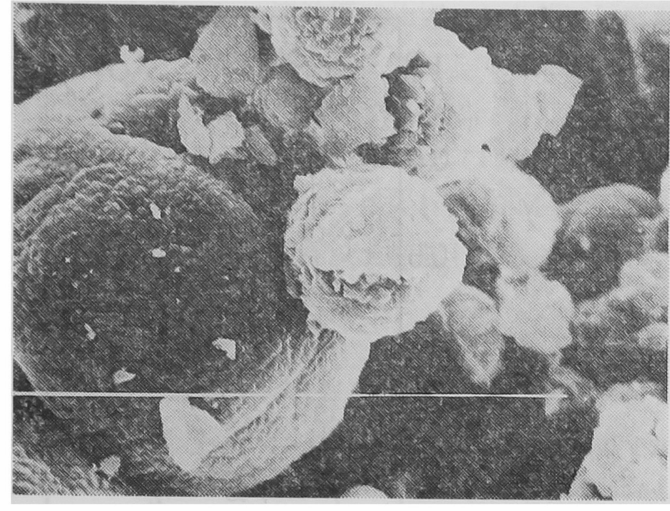

5-1

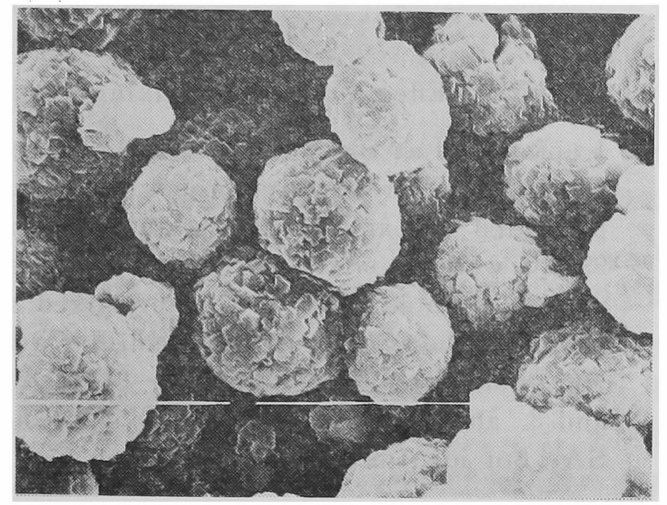

5-3

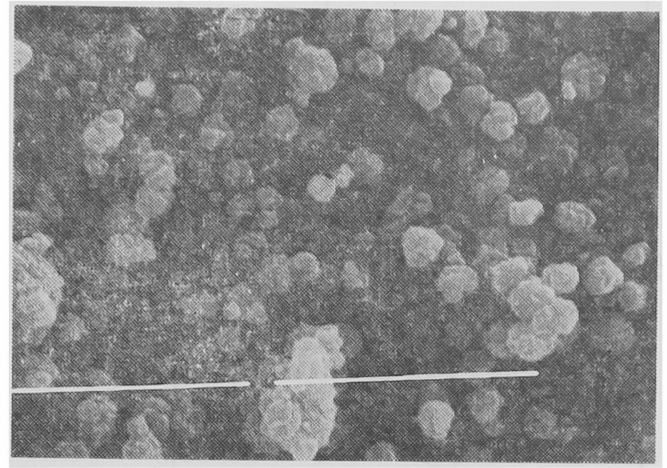

5-2

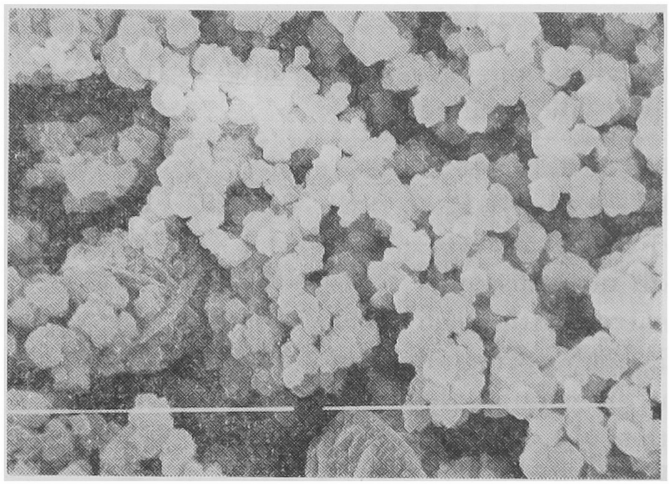

5-4

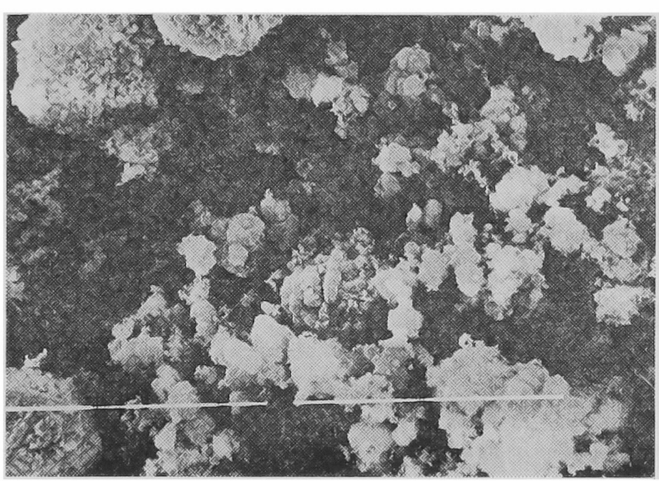

5-5

Fig. 5 Scanning electron micrographs of the products

5-1 : chabazite + gmelinite, the final product of run 3 in Fig. 4, $5-2$ : zeolite $\mathrm{Y}\left(I / I_{\mathrm{s}}=1.02\right)$, the final product of run 1 in Fig. 4, 5-3: zeloite $\mathrm{Y}\left(I / I_{\mathrm{s}}=1.00\right)$, the final product of run 2 in Fig. 4, 5-4 : zeolite $\mathrm{Y}\left(I / I_{\mathrm{s}}=0.886\right)$ and spherulites of chabazite+gmelinite, the final product of run 2 in Fig. 6, 5-5: zeolite $\mathrm{Y}\left(I / I_{\mathrm{s}}=0.395\right)$, chabazite+gmelinite and amorphous solid. Interstice between two lines means $1 \mu \mathrm{m}$ in each figure.

のほど生成する核の数が制限されるものと考えられる。A型ゼオ ライトやX型ゼオライトと異なる点は，Y型ゼオライトの粗粒は 単結晶ではなく, 多結晶集合体であることである。これは, 室温 での混合と分配の間に生成した数少ない核が結晶化の過程で自ら が核発生に寄与した（自触的核生成の中心となった）結果ではな いかと考えられる。

室温での原料溶液を確実に行い, 熟成も十分行って結晶化して も，バッチ組成の $N$ 值を低くし， $S$ 值を高くすると，リョウフッ 石とクメリナイトが副生する。図 6 は 0.259-9.81-41.0 のバッ チ組成で結晶化温度を $99.5^{\circ} \mathrm{C}$, および $105.2^{\circ} \mathrm{C}$ とした場合のゼオ
ライトの生成量の変化である。このバッチ組成ではいずれも（リ ョウフッ石十グメリナイト, 図 5-4 の球晶) が生成するが, その 生成はいす゚れも Y 型ゼオライトの生成とほとんど同時に開始し, また，汪とんど同時に終息する。図 6 に示した黒い小丸は 10 本の回折線の高さの和から求めた Y 型ゼオライトの生成率で, （111）回折線の面積から求めた值とよく一致している。これらの 結果はバッチ組成の $N$ が低下し, 結晶化温度が上昇するとリョウ フッ石拉よびグメリナイトの生成に適した部分が反応混合物中に 生成することを示している。

0. 254-10.0-41.1 では Y 型ゼオライトの最大生成率は大略 


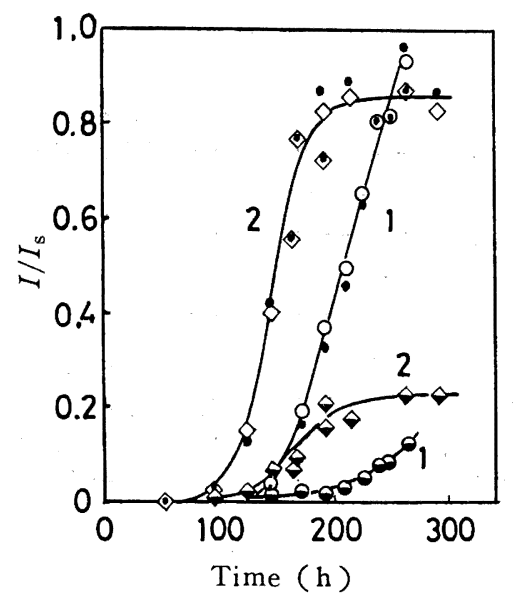

Fig. 6 Effect of crystallization temperature Ageing $; 25^{\circ} \mathrm{C}, 24 \mathrm{~h}$, silica source $=\mathrm{S}-30 \mathrm{H}, \mathrm{N}-\mathrm{S}-\mathrm{H}$ $=0.259-9.81-41,1:(\bullet)$ zeolite $\mathrm{Y}$ caluculated from peak heights, (O) zeolite Y calculated from peak area of (111) line, ( $\Theta$ ) chabazite + gmelinite calculated from the sum of areas of two main peaks, Crystallization; $99.5^{\circ} \mathrm{C}, 2:(\bullet)$ zeolite $\mathrm{Y}$ (peak heights), $(\diamond)$ zeolite Y (peak area), $(\diamond)$ chabazite + gmelinite, Crystallization $=105.2^{\circ} \mathrm{C}$

40\% で，その時点での（リョウフッ石十グメリナイト）の含有率 は $42 \%$ であった。それ以外の結晶は認められないから, 大略 $18 \%$ の非晶質固相が残留する条件で，Y 型ゼオライトの生成が 停止していることになる（図 5-5)。

バッチ組成を 0.247-12.3-44.9 にすると, Y型ゼオライトが 生成しないのみならず，他のゼオライト種も生成しない。目的と するゼオライトを安定的に得るために, 熟成(12)18)47149)执よび種晶 を添加する方法677)40150)が試みられている。これらはいずれも成長 可能な核を保障する意味があり，これらの方法が有効な場合には 誘導期間を短縮することができる。

0.247-12.3-44.9 のバッチ組成で種晶添加と熟成の効果を検 討した。その結果, かき混ぜ直後に種晶を添加した場合, あらか じめかき混ぜておき, 種晶を添加した後にも再度ウルトラディス

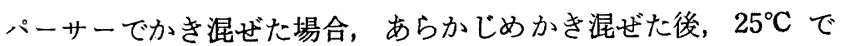
$1 ， 3 ， 6 ， 10$, および 25 時間熟成した後, 種晶を添加した場合, 種晶を添加せずに $15,20,24,25$ 時間熟成した場合, のいずれに 扣いても， $99.5^{\circ} \mathrm{C}$ で $4 \sim 9$ 日間の結晶化期間では非晶質固相以 外の生成は認められなかった。この結果は 0.247-12.25-44.9 のバッチ組成では核生成のみならず，種晶の成長による結晶化も 行われていないことを示している。

バッチ組成が $0.3-9.81-40.9$ から 0.259-9.81-41.0 まで 変化した場合の結晶化曲線を還元結晶化時間で比較すると図 7 の ようになる。図ではそれぞれのY型ゼオライトの最大生成率を生 成量 1.0 にしてあり，N=0.259 の例は図 6 に示したものと同じ で，最大生成率はそれぞれ 97.9 および $88.6 \%$ である。 $N$ 值の 低下は結晶化速度を低下させるだけでなく, 結晶化曲線が S 字形 から直線に近くなり，両対数プロットの勾配は 7.27 から 5.56 まで低下する。この結果は $N$ 值の低下によって結晶化速度が低下

49) A. Yoshida, K. Inoue, Zeolites, 1986, 467.

50）吉田 章, 井上耕三，日化，1982，1466.

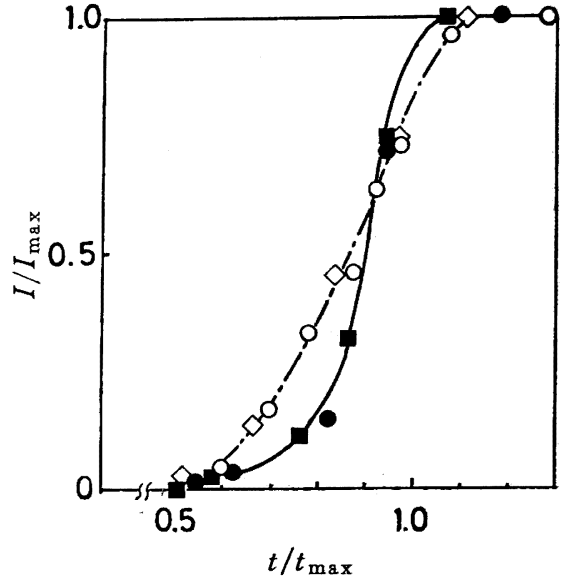

Fig. 7 Changes of crystallization curves with decreasing $\mathrm{Na}_{2} \mathrm{O} / \mathrm{SiO}_{2}$ molar ratio of reaction mixture

Ageing; $25^{\circ} \mathrm{C}, 24 \mathrm{~h}$, silica source $=\mathrm{S}-30 \mathrm{H}$, run 1 ; (घ) $0.3-9.81-40.9,99.5^{\circ} \mathrm{C}$, run 2 ; (O) $0.292-$ $9.81-41.9,99.5^{\circ} \mathrm{C}$, run 3 ; (O) $0.259-9.81-41.0$, $99.5^{\circ} \mathrm{C}, I_{\max } / I_{\mathrm{s}}=0.979$, run $4 ;(\diamond) 0.259-9.81-41.0$, 105. $2^{\circ} \mathrm{C}, I_{\max } / I_{\mathrm{s}}=0.886$

For identifications of $I, I_{\max }, I_{\mathrm{s}}, t$ and $t_{\max }$, see Fig. 2 and 3 legend

するとともに，結晶化初期における自触的核生成もしだいに抑制 されることを示す。

$N$ 值を低下させ， $S$ 值を増加させた場合に生成する $\mathrm{Y}$ 型ゼオラ イトの最大生成率と格子定数の関係を図 8 に示した。 $\mathrm{Si}-\mathrm{O}$ 間の 距離は $\mathrm{Al}-\mathrm{O}$ 間の距離にくらべてわずかに小さいので, $\mathrm{Y}$ 型ぜオ ライトの $\mathrm{SiO}_{2} / \mathrm{Al}_{2} \mathrm{O}_{3}$ モル比が高くなるにつれて格子定数は小さ くなる。格子定数と $\mathrm{Y}$ 型ゼオライトの $\mathrm{SiO}_{2} / \mathrm{Al}_{2} \mathrm{O}_{3}$ モル比（化学 分析値）の関係は 1964 年に Breck らによって初めて報告され た。高シリカ $\mathrm{Y}$ 型ゼオライトの開発とともに, 特許9)14)51)にもそ

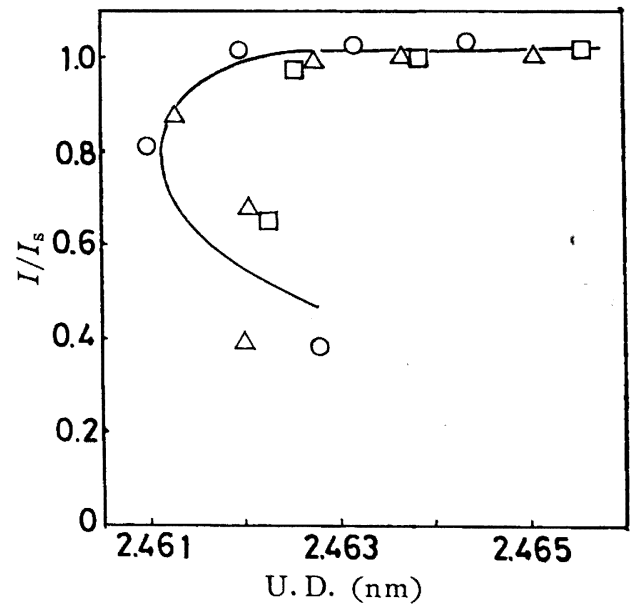

Fig. 8 Correlations between the maximum yields of zeolite $\mathrm{Y}$ and the unit cell dimensions

Silica source and crystallization temperaure ; (O) $\mathrm{VN}-3,90^{\circ} \mathrm{C},(\square) \mathrm{VN}-3,99.5^{\circ} \mathrm{C},(\triangle) \mathrm{S}-30 \mathrm{H}$, 99. $5^{\circ} \mathrm{C}$

For identification of $I / I_{\mathrm{s}}$, see Fig. 2 legend

51) D. D. Maness, U.S. P. 3, 701,629(1972). 
の記載がみられる。その後, MASNMR が開発され NMR によ る $\mathrm{SiO}_{2} / \mathrm{Al}_{2} \mathrm{O}_{3}$ モル比と格子定数の関係が報告されている ${ }^{521 \sim 54)}$ 。 Kerr $^{55)}$ も指摘しているがそれらの值はほとんどが Breck らの 相関式と, Sohn ら51)の相関式によって示される二つの直線の間 に入る。著者は LZ-Y 52, 参照触媒の JRC-Z-Y 4.8 と JRC-ZY 5.6, および今回合成した高シリカ $\mathrm{Y}$ 型ゼオライトのうち結 晶性のよい 5 試料について格子定数と MASNMR から求めた $\mathrm{SiO}_{2} / \mathrm{Al}_{2} \mathrm{O}_{3}$ モル比の関係を調べた。その結果, 著者の得た值は Breck ら 2)の相関式に最も近いが, Breck らの式から求めた值よ り少し大きくなることが判明した。著者の測定した試料にはー84 ppm に Si (4 A1) が, また, $-110 \mathrm{ppm}$ に非晶質固相として のシリカがいずれも少量ずつ認められた ${ }^{43)}$ 。格子定数が 2.462 $\mathrm{nm}$ まではY型ゼオライトの結晶含有率はほとんど変化しない。 2. $462 \mathrm{~nm}$ の結晶の MASNMR による $\mathrm{SiO}_{2} / \mathrm{Al}_{2} \mathrm{O}_{3}$ モル比は非晶 質固相を含めないで計算すると 3 回の波形解離で $6.00 \pm 0.10$ の 範囲になり ${ }^{43)},-110 \mathrm{ppm}$ の非晶質固相を加えた全固相の值では 6. $16 \pm 0.10$ となる。化学分析值は 6.04 で, NMR で求めた非晶 質固相の分率を用い, 非晶質固相を $\mathrm{SiO}_{2}$ とみなして化学分析値 から結晶の $\mathrm{SiO}_{2} / \mathrm{Al}_{2} \mathrm{O}_{3}$ モル比を求めると $5.87 \sim 5.90$ となり, MASNMR から求めた值と比較的によく一致した。な拉, Breck $ら^{2)}$ の相関式から計算した値は 5.77 , Sohn $5^{52)}$ の式では 7.39 と なる。

格子定数が $2.462 \mathrm{~nm}$ 以下になるとリョウフッ石とグメリナイ トの生成率がいちじるしく増加し, 格子定数は $2.461 \mathrm{~nm}$ まで咸 少する。さらにNを低下させ， $S$ を増加させるとリョウフッ石と グメリナイト以外に非晶質固相が共存し（図 5-5), Y型ゼオライ トの格子定数は再び $2.463 \mathrm{~nm}$ まで大きくなる。この声の結晶の $\mathrm{SiO}_{2} / \mathrm{Al}_{2} \mathrm{O}_{3}$ モル比は 5.96 近くまで減少している。結局, 本实験 で生成したY型ゼオライトの格子定数の下限は $2.461 \sim 2.462 \mathrm{~nm}$ で, $\mathrm{SiO}_{2} / \mathrm{Al}_{2} \mathrm{O}_{3}$ モル比の上限は 6.0〜6.1 であると考えられる。

\subsection{Y 型セオライトの生成過程}

Y 型ゼオライトが生成する過程の固相の ${ }^{29} \mathrm{Si}-\mathrm{MASNMR}$ スペ クトルを㘠 9 に示した。図 9 の A はバッチ組成が 0.3-9.8140.9 で S-30 H をシリカ源とする例だが, Ginter ら ${ }^{45) か ゙ ~} 0.307-$ 13-47.5 のバッチ組成で生成したY型ゼオライトについて液相一 固相過程で報告したものと同様に, 結晶化が進むにつれて共鳴吸 収ピークが低磁場側にシフトしている。一方，Bはバッチ組成が 0. 28-10-42.8 で SA をシリカ源とする例（図 4-1 と同じ試料） で, $25^{\circ} \mathrm{C}$ で 24 時間熟成した時点でシリカゾルの構造を維持して いることを示す $-112 \mathrm{ppm}$ のピークのほかに， $-84 \mathrm{ppm}$ に非晶 質の $\mathrm{Si}(4 \mathrm{Al})$ に帰属するピークが認められた。この混合物は $99.5^{\circ} \mathrm{C}$ で 1 時間加熱すると， $-95 \mathrm{ppm}$ に頂点を有するなだら かな一つのピークを持つゲルに変化した。このなだらかなピーク は結晶化によって分離する五つのピークのほぼ中央に位置する。 Engelhardt ら ${ }^{56)}$ はA 型ゼオライトの結晶化過程を ${ }^{29} \mathrm{Si}-\mathrm{MAS}$ NMR と ${ }^{27} \mathrm{Al}-\mathrm{MASNMR}$ で検討し, 非晶質の段階でA型ゼオラ

52) J. R. Sohn, S. J. Decanio, J. H. Lunsford, D. J. O’Donnell, Zeolites, 1986, 225.

53) H. Fichtner-Schmittler, U. Lohse, G. Engelhardt, V. Patzelova, Cryst. Res. Tech., 19, K 1(1984).

54) H. K. Beyer, I. M. Belenkaja, F. Hange, J. Chem. Soc., Faraday Trans., 81, 2889(1985).

55) G. T.Kerr, Zeolites, 1989, 350.
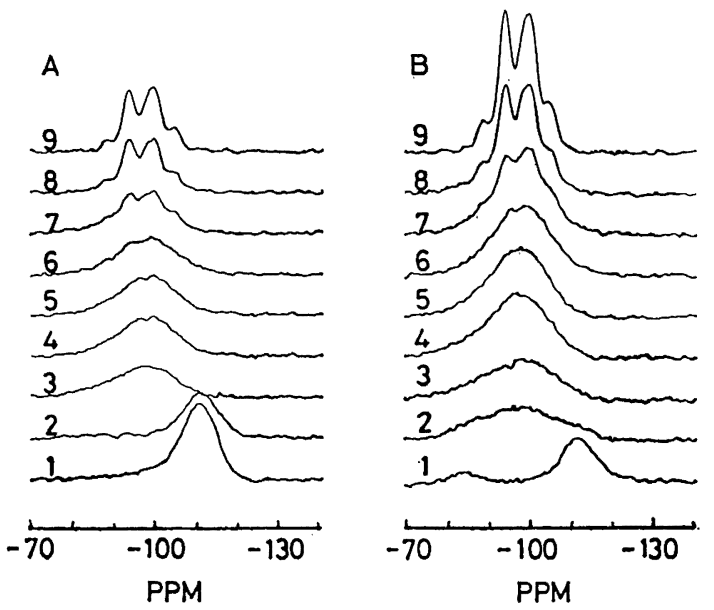

Fig. $9{ }^{29} \mathrm{Si}-\mathrm{MAS}-\mathrm{NMR}$ spectra of solid phases on the course of crystallization of zeolite $\mathrm{Y}$

A : run 1 inFig. $7 ; 1=25^{\circ} \mathrm{C}, 1 \mathrm{~h}, 2=25^{\circ} \mathrm{C}, 24 \mathrm{~h}, \mathrm{Cry}-$ stallization time, $3=20 \mathrm{~h}, 4=40 \mathrm{~h}, 5=46 \mathrm{~h}(0.03)$, $6=61 \mathrm{~h}(0.114), 7=68 \mathrm{~h}(0.32), 8=75 \mathrm{~h}(0.70), 9=$ $85 \mathrm{~h}$ (1.02), B : run 1 in Fig. $4 ; 1=25^{\circ} \mathrm{C}, 24 \mathrm{~h}, \mathrm{Cry}-$ stallization time, $2=1 \mathrm{~h}, 3=3 \mathrm{~h}, 4=17 \mathrm{~h}, 5=42 \mathrm{~h}$ (0.011), $6=50 \mathrm{~h}(0.028), 7=66.5 \mathrm{~h}(0.261), 8=74 \mathrm{~h}$ (0.639), $9=89 \mathrm{~h}(1.016)$

Values in brackets are $I / I_{\mathrm{s}}$, All ${ }^{29} \mathrm{Si}$ spectra are referenced to tetramethylsilane $(0 \mathrm{ppm})$

イトに特有のショルダーが現れ，それが徐々に対称性のよい鋭い ピークに変化することから，ゲル固相の再配列による結晶化を推 論している。図 $9 \mathrm{~B}$ は同様の結果であるよ5にみえる。しかし， Y 型ゼオライトの前駆体固相（非晶質）では多くの構造欠陥を含 み, 当然 $\mathrm{Si}(n \mathrm{Al}) \mathrm{OH}$ 原子団を有するので, $\mathrm{Al}$ に対する結合数 が同じでも，共鳴吸収ピークが低磁場側にシフトしていることが 考えられる ${ }^{57)}$ 。そこで, 図 $9 \mathrm{~B}$ の試料の化学分析拈よび格子定数 から計算した $\mathrm{SiO}_{2} / \mathrm{Al}_{2} \mathrm{O}_{3}$ モル比を調へ，液相組成の変化と対比 した（図 10，11）。結晶の $\mathrm{SiO}_{2} / \mathrm{Al}_{2} \mathrm{O}_{3}$ モル比は Breck ら ${ }^{2)}$ の式 を用いて格子定数から計算した值を示した。

固相の化学分析值による $\mathrm{SiO}_{2} / \mathrm{Al}_{2} \mathrm{O}_{3}$ モル比は熟成の完了した 特点で 11.5 で, バッチ組成の $S$ 值より大きい。これはシリカゾ ルがほとんど溶解せず, 液相のアルミナが完全にはシリカと結合 していないことによっている。結晶化 1 時間で, シリカゾルの溶 解は完了し, $\mathrm{SiO}_{2} / \mathrm{Al}_{2} \mathrm{O}_{3}$ モル比が 5.9 のシリカーアルミナゲルと なるが，時間の経過とともに，いったん液相に溶解したシリカを 取り込んで $\mathrm{SiO}_{2} / \mathrm{Al}_{2} \mathrm{O}_{3}$ モル比が大略 7 の非晶質固相となる。次 に, Y 型ゼオライトの結晶が現れると, 固相全体の $\mathrm{SiO}_{2} / \mathrm{Al}_{2} \mathrm{O}_{3}$ モル比は徐々に減少し, 結晶化が完了した時点で 5. 98〜 5.99 と なった。一方, Y型ゼオライトの $\mathrm{SiO}_{2} / \mathrm{Al}_{2} \mathrm{O}_{3}$ モル比はX線回折 線のピークが特定できる範囲で一定 (Breck らの式で 5.58土 0.08）であり，蔭山ら ${ }^{58)}$ の結果とよい一致をみた。これは，熟成 を十分行わなかった例（図 4-2）でも同様の結果となった。結晶 化が完了した時点の試料の MASNMR による $\mathrm{SiO}_{2} / \mathrm{Al}_{2} \mathrm{O}_{3}$ モル

56) G. Engelhadt, B. Fahlke, M. Magi, E. Lippmaa, Zeolites, 1983, 292.

57) G. J. Ray, A. G. Nerheim, J. A. Donohue, ibid., 1988, 458.

58）蔭山信夫, 上田 智, 小泉光恵, 日化, 1981， 1510. 


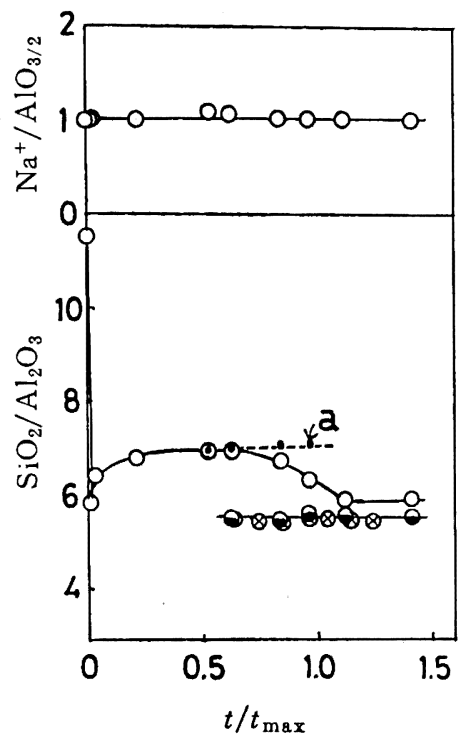

Fig. 10 Changes of solid compositions on the course of zeolitization

All samples are the same with in Fig.4, (O) solid phase of run 1, ( $\Theta$ ) zeolite $Y$ of run $1,(--\bullet--)$ amorphous of run $1,(\otimes)$ zeolite $\mathrm{Y}$ of run 2

比は結晶部分が $5.82 \pm 0.13$ の範囲であり, 非晶質固相は 1.2 $3.6 \%$ の範囲で検出され，非晶質固相を含む全固相の $\mathrm{SiO}_{2} / \mathrm{Al}_{2}$ ・

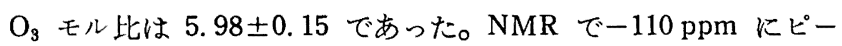
クを有する非晶質固相は結晶粒界などの結晶構造が不完全な場所 に夾雑していると考兄, それらを含む結晶相の $\mathrm{SiO}_{2} / \mathrm{Al}_{2} \mathrm{O}_{3}$ モル 比を 5.985 として, 未反応の非晶質固相の $\mathrm{SiO}_{2} / \mathrm{Al}_{2} \mathrm{O}_{3}$ モル比を 計算した（図 10 の点線）。結局, 固相の $\mathrm{SiO}_{2} / \mathrm{Al}_{2} \mathrm{O}_{3}$ モル比が徐 々に減少しているのは $\mathrm{SiO}_{2} / \mathrm{Al}_{2} \mathrm{O}_{3}$ モル比の低い結晶相の割合が 增えているからで, 未反応の非晶質固相の組成は結晶化過程で注 とんど変化していないるのと考光られる。ゲル粒子の中で結晶化 が進行して結晶の比率が 64\% になったとき（図 10-a）の結晶粒 子径の大きさは，非晶質固相と結晶の比重が等しいと仮定する と, ゲル粒子径の $86.2 \%$ に相当する。Y型ゼオライトが固相固相反応で結晶化すると仮定すると, 当然結晶に隣接する非晶質 固相の $\mathrm{SiO}_{2} / \mathrm{Al}_{2} \mathrm{O}_{3}$ モル比は結晶のそれに近い值でないといけな い。しかも，末反応の非晶質固相の平均的 $\mathrm{SiO}_{2} / \mathrm{Al}_{2} \mathrm{O}_{3}$ モル比が 7.2 なので, 粒子の外表面近傍での $\mathrm{SiO}_{2} / \mathrm{Al}_{2} \mathrm{O}_{3}$ モル比は 8 以上 にならなければならない。粒子径の僅か $14 \%$ ，層厚でわずか $7 \%$ の非晶質固相内にその上らな組成変化が生じているとは考学がた いので，因 9-B の例でも，液相-固相過程で結晶化しているもの と推論した。

洗浄した固相の $\mathrm{Na}_{2} \mathrm{O} / \mathrm{Al}_{2} \mathrm{O}_{3}$ モル比は熟成直後から結晶化完了 までの間で $1.05 \pm 0.05$ で一定である。すなわち，固相の 1 個の $\mathrm{Al}$ 原子の陽電荷を大略 1 個の $\mathrm{Na}^{+}$イオンが補完しており，非晶 質固相の構造もゼオライトの基本的構造に類似していると考えら れる ${ }^{48)}$ 。

結晶化の過程で，溶液中のシリカが増加し，アルミナが減少し ているにもかかわらず， $\mathrm{Na}^{+}$イオンが增加しているが，これにつ いては，次のように考兄られる。誘導期の非晶質固相を棚板付き 遠心分離管を用いて 8000 10000 gee で遠心分離して得られる夜

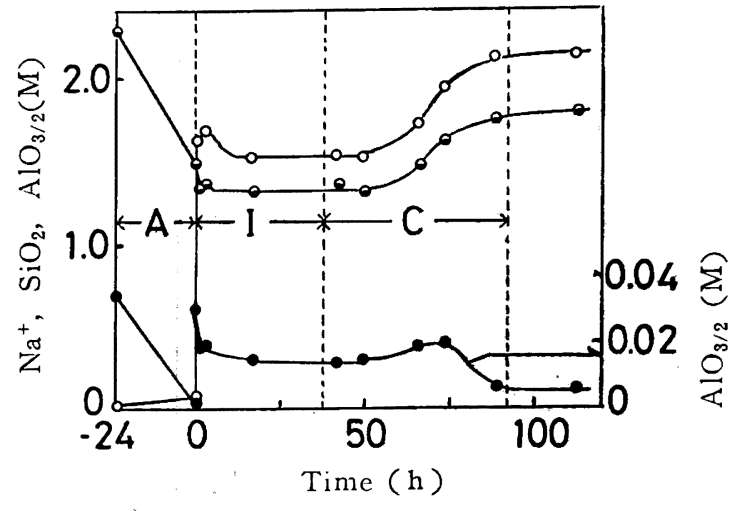

Fig. 11 Changes of liquid compositions

Samples are the same with run 1 in Fig. 4, $\mathrm{A}=$ ageing, $\mathrm{I}=$ induction period, $\mathrm{C}=$ crystallization, (Ө) $\mathrm{Na}^{+}$, (O) $\mathrm{SiO}_{2}$, (O) $\mathrm{Al}_{2} \mathrm{O}_{3}$

相の量は，同じ温度，同じ遠心効果で結晶から除去できる液相の 量より少ない。また，遠心効果を変化させて液相の $84 〜 94 \%$ を $3 \sim 4$ 回に分けて部分的に分取した液相の組成はほとんど変化が なく，遠沈管で分取できる上澄み液の組成と大差ないが，遠心分 離した固相を洗浄すると液相よりも $\mathrm{Na}^{+} / \mathrm{SiO}_{2}$ モル比の高い洗夜 が得られる。したがって，非晶質固相では過剩な $\mathrm{Na}^{+}$イオンが 固相の表面に存在し，それが余分な水分子を引き付けているもの と考党られる。非晶質固相では結晶にくらべて未結合の末端基 ( $\mathrm{SiOH})$ が多いが，それらは Polak ら 25126)が指摘しているよ5に $\mathrm{Na}^{+}$イオンを含むアルカリ性溶液と接した状態では，SiONa の 形をとるものと考元られる。

結晶化による液相のアルミナの濃度变化は $0.007 \sim 0.0125 \mathrm{M}$ の籁囲である。この量は固相のアルミナの $0.7 \sim 1.3 \%$ にすぎな い。固相のアルミナの変化量を無視して, $\mathrm{SiO}_{2} / \mathrm{Al}_{2} \mathrm{O}_{3}$ モル比から 結晶化過程での固相のシリカの減少量を計算すると, 図 10 の例 では $14.3 \%$ となる。今回実験した組成範囲で溶出した $\mathrm{Na}^{+}$イ オンの量は溶出シリカ量に対して $\mathrm{Na}^{+} / \mathrm{SiO}_{2}$ モル比で 0.66 0.93 の範囲にあり, すべての系で $\mathrm{Na}^{+}$イオン 1 個が溶出する 時に，1～2 個のシリカ分子を一緒に溶出していることになる。 固相一固相過程を仮定すると，これはシリカ分子 7 個に 1 個 の割 合で末端基のシリカ分子が溶出する間に結晶化が完了することを 意味するが，完全に不規則な構造がそれくらいの調整で結晶構造 に変化するとは考光難い。骨格構造の手直しの部分を増やすため に，未結合の末端基を有する部分が存在するにも関わらず，すで に四つの結合が满たされた部分（Tサイト）が再溶解し, 修復箇 所を增やすと仮定すると，それはかぎりなく再溶解過程を含む液 相一固相過程に近づく。

図 12 は固相に含まれる $\mathrm{Y}$ 型ゼオライトの $\mathrm{X}$ 線回折強度比に対 して液相組成をプロットしたものである。バッチ組成の $N$ 值が低 下しても, 結晶化過程でのアルミナ濃度はあまり变化しない。シ リカ濃度も結晶化初期に若干低くなる傾向にあるが, 結晶化が 完了した時点では同じ水準まで増加している。たたし， $N$ 值が 低く、リョウフッ石とグメリナイトが共存する系では，液相の $\mathrm{Na}^{+} / \mathrm{SiO}_{2}$ モル比が結晶化の進行とともに減少している。一方, 原料を加熱し，混合過程でも保温した系（図 4-4）ではシリカ濃 度もアルミナ濃度も結晶化過程のそれらと同等か,むしくはそれ 


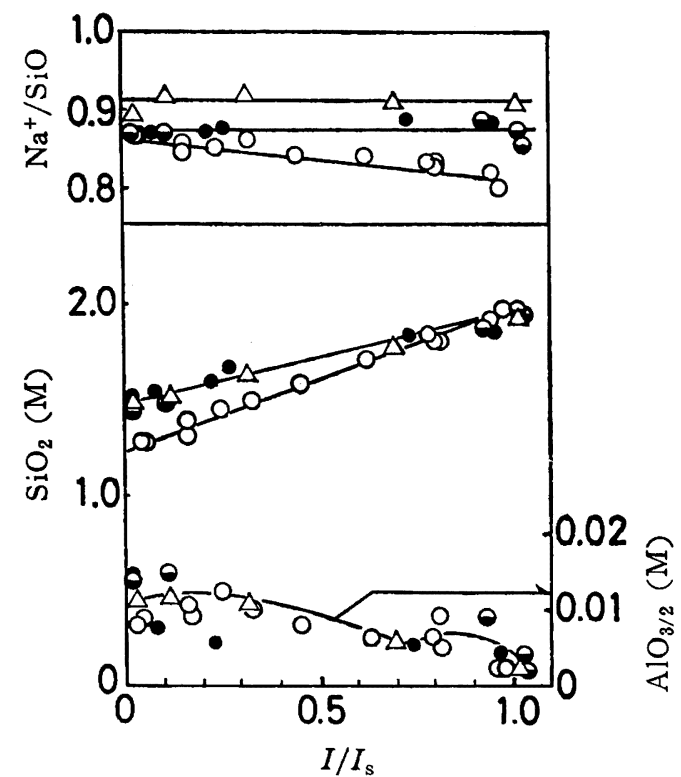

Fig. 12 Correlations between $I / I_{\mathrm{s}}$ and concentrations of $\mathrm{Na}^{+}, \mathrm{SiO}_{2}, \mathrm{Al}_{2} \mathrm{O}_{3}$ and $\mathrm{Na}^{+} / \mathrm{SiO}_{2}$ in liquid phases

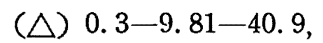
$0.292-10-41.1,(\Theta)$

$0.28-9.81-40.9$, (○) $0.259-9.81-41$, Ageing ;

$25^{\circ} \mathrm{C}, 24 \mathrm{~h}$, Crystallization ; $99.5^{\circ} \mathrm{C}$

より高い值を示したが, $\mathrm{Na}^{+} / \mathrm{SiO}_{2}$ モル比は混合終了時に 0.875 である以外は $0.675 \sim 0.779$ で推移し，いかなるゼオライトも生 成しなかった。

\subsection{Y 型ゼオライトの生成機構}

熟成期間中における核の生成については, アルミン酸イオン濃 度の高い条件でY型ゼオライトの核生成が行われると考えられ る。図 11 の結果は今回使用したすべてのシリカ源に共通の結果 であり, 熟成終了時のアルミン酸イオンの濃度がシリカ源の一次 粒子径によってわずかに異なる（粒径が小さいものほど低い）の みで, 熟成期間中のケイ酸イオン濃度はいずれも極めて低く， ア ルミン酸イオンと $\mathrm{Na}^{+}$イオンの濃度のみが高い。Polack ら 25)26) はあらかじめシリカゾルをアルカリ溶液と混合した後にアルミン 酸ナトリウム溶液と混合すると, Y 型ゼオライトが生成せずにグ メリナイトが生成したと報告しているが，これは，シリカの溶解 が促進された結果, 混合終了時のケイ酸イオンとアルミン酸イオ ンの濃度が逆転し，アルミン酸イオン濃度がいちじるしく低い条 件で熟成したためと考えられる。

複雑なゼオライトの結晶構造に寄与しらる溶液中のアルミノヶ イ酸イオン種の存在は Barrer $5^{59) 60)}$, Kerr ${ }^{61)}$, Ciric ${ }^{46)}$ および

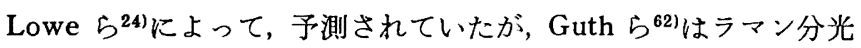
法で, Fahlke ら ${ }^{42)}$ はモリ゙デン黄法で, また, Kasahara ら ${ }^{291}$, Ueda $5^{63)}$, Glasser $5^{64)}$, McCormic 5 ${ }^{65)}$, および Ginter ら ${ }^{45)}$ は NMR 法によって液相溶存種の同定を行った。McCormic

59) R. M. Barrer, J. W. Baynham, F. W. Bultitude, W. M. Meier, J. Chem. Soc., 1959, 195.

60) R. M. Barrer, Chemistry in Britain, 1966, 380.

61) G. T. Kerr, J. Phys. Chem., 70, 1047(1966).

62) J. L.Guth, P. Caullet, R. Wey, "Proceedings of the Fifth International Conference on Zeolites", (Ed. L. V. Rees), Heyden, London (1980) p. 30.
ら ${ }^{65)}$ の最近の報告では, 最も重合度の高いシリカの溶存種は二重 六員環 (D6R) である。しかし, この湘定は室温でアルミン酸イ オンが存在しない系で行われたものであり, 結晶化温度では溶存 種は解離する傾向があること，また，アルミン酸イオンの存在下 では沈澱を生成しやすいことなどから，D６Ｒをを越える重合度の 溶存種の存在は疑問である。既報48)で報告したようにホージャサ イト型ゼオライトとリョウフッ石拉よびグメリナイトの微細構 造は単一四員環の配置でみると極めて類似しており，いずれも D $6 \mathrm{R}$ を基本構成単位としている。Ueda $5^{68)}$ が指摘しているよ らに, 液相溶存種の構造の差からゼオライト種の構造の差を帰結 するのは難しい問題を含んでいる。類似した構造を識別するには 複雑な液相溶存種を想定する必要があり, 溶存種の複雑な䨀造を 想定するとそれらが結合する仕方が限定されてくる。特定の方向 でのみ結合するよらにしないと目的とする構造にいたらない。ま た, 特定の結晶構造のみをつくり出す特定の溶存種のみが存在す るという仮定は, 複数の溶存種の共存を示す NMR の結果に反 ナる。

液相の $\mathrm{Na}^{+} / \mathrm{SiO}_{2}$ モル此が低い条件で $\mathrm{Y}$ 型ゼオライトの生成が 遅延する結果は, 液相のケイ酸イオンの重合度が増加すると結晶 化に支障をきたすことを意味しており，Schwochow ら ${ }^{33)}$ の結果 と一致する。これまでの論議は主としてどのようなブロックを積 み重ねていくか28159160)，というところに視点が扐かれていた。し かし, 微細構造から出発するかぎり, 前述のよらな矛盾は避けら れない。むしろ, 結晶化の過程でシリカ骨格は何を支えにして, 空洞構造を積み重ねるのかといら観点に立つ方がよいように思わ れる。夜相の中のそれらを支える分子種として $\mathrm{Na}^{+}$イオンを核 とする水和イオン, 拉よび $\mathrm{Na}^{+}$イオンの電荷を中和する陰イオ ンの対を想定し，その水和イオン対の大きさがゼオライトの細孔 構造を決める要因になると仮定すると, 高温での混合で核が生成 しないことも，高温で細孔構造の小さなリョウフッ石 ${ }^{66)}$ とグメリ ナイトの生成が促進されることも説明できる。

$N$ 值の低下が結晶化速度を遅延させ，自触的核生成を抑制し， リョウフッ石とグメリナイトの生成を助長することは, 夜相-固 相過程を想定すれば説明できる。液相のケイ酸イオン,およびア ルミノケイ酸イオン濃度が増加し, 重合が進むといらことは $\mathrm{Na}^{+}$ イオンの活動度の低下を意味し, 非晶質固相の再溶解を遅延させ る。熟成時間を短くし，誘導期間を 2 倍らかくに延ばしても生成 する $\mathrm{Y}$ 型ゼオライトの $\mathrm{SiO}_{2} / \mathrm{Al}_{2} \mathrm{O}_{3}$ モル比がほとんど変わらない こと,および, 結晶の量が $\mathrm{X}$ 線回折法で測定出来る量になり, 結 晶化によって新たに溶出したイオンを加えて液相組成の $\mathrm{Na}^{+}$イ オンとケイ酸イオンの濃度が増加して初めて自触的核生成が行わ れること（図 4-1，-2 および図 11）女，Y型ゼオライトの生成

63) S. Ueda, N. Kageyama, M. Koizumi, "Proceedindgs of Sixth International Zeolites Conference", (Eds. D. Olson, A. Bisio), Butterworth (1984) p. 905.

64) L.S. D. Glasser, G. Harvey, "Proceedindgs of Sixth International Zeolites Conference”, (Eds. D. Olson, A. Bisio), Butterworth (1984) p. 925.

65) A. V. McCormic, A.T. Bell, C. J. Radke, "New Development in Zeolites Science and Technology", (Eds. Y. Murakami, A. Iijima, J. W. Ward), Kodansha, Tokyo (1986) p. 247.

66) 冨永博夫編, “ゼオライトの科学と応用”, 講談社 (1987). p. 12. 
反応が液相一固相過程であることを示唆している。

$\mathrm{Na}^{+}$イオンおよびそれを含む水和イオン対が結晶構造内にと りこまれて，結晶化が進行しているのか，もしそらだとしてそれ
はどらいうイオン対なのか, それとも, 結晶成長界面の未結合の 末端基を満たす形で $\mathrm{Na}^{+}$水和イオンがついているのかといらこ とについては，今後さらに子細に研究しなければならない。

\title{
Synthesis of High-silica Zeolite $Y$
}

\author{
Akira Yoshida \\ Government Industrial Research Institute, Kyushu; Shuku-machi, \\ Tosu-shi 841 Japan
}

Zeolite $\mathrm{Y}$ with $\mathrm{SiO}_{2} / \mathrm{Al}_{2} \mathrm{O}_{3}$ molar ratios $=5.5 \sim 6.0$, were synthesized from the reaction mixtures whose molar ratio were (2.541-2.943) $\mathrm{Na}_{2} \mathrm{O}-\mathrm{Al}_{2} \mathrm{O}_{3}-(9.81-13) \mathrm{SiO}_{2}-(104.2-120.4) \mathrm{H}_{2} \mathrm{O}$, using colloidal silica, silica sol and sodium aluminate solution. The changes in chemical composition of solid and liquid phases on the course of zeolitization were analyzed by XRD, MASNMR, SEM observation, and chemical analyses. After the ageing at $25^{\circ} \mathrm{C}$ for $24 \mathrm{~h}$, only a small amount of silica reacted with sodium aluminate solution, and the concentration of silica in liquid phase was very low. After the heating at $99.5^{\circ} \mathrm{C}$ for $1 \mathrm{~h},{ }^{29} \mathrm{Si}-\mathrm{MASNMR}$ signals shifted to lower fields, and the concentration of silica species increased up to $1.2 \sim 1.6$ $\mathrm{mol} / \mathrm{dm}^{3}$, though the concentration of aluminate ions decreased to $0.01 \sim 0.02 \mathrm{~mol} / \mathrm{dm}^{3}$. During the induction period, the concentrations in liquid compositions were kept at nearly constant. With decreasing $\mathrm{Na}_{2} \mathrm{O} / \mathrm{SiO}_{2}$ molar ratio of reaction mixture, $\mathrm{Na}^{+} / \mathrm{SiO}_{2}$ ratio in liquid phase decreased. When the value of $\mathrm{Na}^{+} / \mathrm{SiO}_{2}$ in liquid phase decreased to 0.84 or less during the crystallization, spherulites of chabazite and gmelinite appeared. The changes of ${ }^{29} \mathrm{Si}$-MASNMR signals seemingly showed the solid-solid transformation mechanism on the formation of zeolite $\mathrm{Y}$. However, the XRD and chemical analyses of solid phases proved the formation of zeolite $\mathrm{Y}$ with $\mathrm{SiO}_{2} / \mathrm{Al}_{2} \mathrm{O}_{3}=5.985$, from amorphous solid with $\mathrm{SiO}_{2} / \mathrm{Al}_{2} \mathrm{O}_{3}=$ 7.0-7.2. These results show the liquid-solid transformation mechanism on the formation of zeolite Y. 